\title{
HYGIENIC AND NUTRITIONAL HABITS IN DENTAL CARIES PREVENTION IN 5-YEAR-OLD CHILDREN FROM BIALA PODLASKA*
}

\author{
Elżbieta Huk-Wieliczukl, Anna Czeczuk ${ }^{l}$
}

\author{
${ }^{1}$ Józef Piłsudski University of Physical Education in Warsaw, Branch in Biala Podlaska, Poland
}

\begin{abstract}
Background. Preschool children are particularly susceptible to dental caries development. Due to the fact that deciduous teeth are less mineralised, they are more likely to be affected by this condition. Therefore, preschool age is a significant period in shaping positive health-oriented attitudes regarding dental caries prevention.

Objective. The aim of this study was to analyse hygienic and nutritional habits in children aged 5 from Biala Podlaska in the context of dental caries prevention.

Material and Method. The study included 454 preschool children (251 boys and 203 girls) from Biala Podlaska. Their hygienic and nutritional habits were examined with a diagnostic survey using the authors' own anonymous questionnaire. Mean consumption of nutrients (calcium, phosphorus and vitamin D) was estimated on the basis of average daily consumption calculated as a mean from three 24-hour interviews (conducted by the authors in a kindergarten or at children's houses). A nutritional value of a daily portion was calculated with the use of "Dieta 5.0" software (National Food and Nutrition Institute).

Results. Research results revealed that in the case of only one in three children, parents began toothbrushing within the first year of a child's life. Approximately $90 \%$ of preschool children brushed their teeth at least twice a day. Half of the children under examination brushed their teeth for 1-2 minutes usually with a traditional toothbrush. Toothbrushing was supervised by $62.5 \%$ of the boys' parents and $38.9 \%$ of the girls' parents $(p<0.05)$. Almost $66 \%$ of the parents took their children to a dentist for regular (once or twice a year) dental check-ups. Analyses of daily food rations revealed insufficient amounts of calcium (25\%) and vitamin D (over 80\%). Moreover, an excessive intake of phosphorus (twice as high as the norm) was noted.
\end{abstract}

Conclusions. Developing appropriate hygienic and nutritional habits in children is an indispensable element in the prevention of lifestyle diseases, including dental caries.

Key words: preschool children, caries, nutritional and hygienic habits

\section{STRESZCZENIE}

Wprowadzenie. Dzieci w wieku przedszkolnym są szczególnie podatne na rozwój próchnicy. Ze względu na fakt, że zęby mleczne są mniej zmineralizowane, istnieje większe prawdopodobieństwo, że dotknie ich ten stan. Dlatego wiek przedszkolny jest znaczącym okresem w kształtowaniu pozytywnych postaw prozdrowotnych dotyczących zapobiegania próchnicy zębów.

Cel. Celem badań była analiza higienicznych i żywieniowych nawyków u dzieci w wieku 5 lat z Białej Podlaskiej w kontekście profilaktyki próchnicy.

Materiał i metody. Badaniem objęto 454 dzieci w wieku przedszkolnym (251 chłopców i 203 dziewczynki) z Białej Podlaskiej. Nawyki higieniczne i żywieniowe dzieci zostały ocenione w badaniu diagnostycznym z wykorzystaniem anonimowego kwestionariusza autorskiego. Średnie spożycie składników odżywczych (wapnia, fosforu i witaminy D) oszacowano na podstawie średniego dziennego spożycia obliczonego jako średnia z trzech 24-godzinnych wywiadów (przeprowadzonych przez autorów w przedszkolu lub w domach dziecka). Wartość odżywczą dziennej porcji obliczono przy użyciu oprogramowania „Dieta 5.0” (National Food and Nutrition Institute).

Wyniki. Wyniki badań ujawniły, że w przypadku tylko jednego na troje dzieci rodzice zaczęli myć zęby w ciągu pierwszego roku życia dziecka. Około $90 \%$ dzieci w wieku przedszkolnym myje zęby co najmniej dwa razy dziennie. Połowa badanych dzieci myła zęby przez 1-2 minuty, zwykle tradycyjną szczoteczką do zębów. Szczotkowanie zębów nadzorowało $62,5 \%$ rodziców chłopców i 38,9\% rodziców dziewcząt $(p<0,05)$. Prawie $66 \%$ rodziców zabierało swoje dzieci do dentysty na regularne (raz lub dwa razy w roku) wizyty kontrolne. Analizy codziennych racji żywnościowych wykazały niewystarczające ilości wapnia (25\%) i witaminy D (ponad 80\%). Ponadto odnotowano nadmierne spożycie fosforu (dwa razy wyższe niż norma).

* Statutory research: DS. 246 - Psychophysical development of five-year-olds children in Biala Podlaska

Corresponding author: Elżbieta Huk-Wieliczuk, Akademia Wychowania Fizycznego im. Józefa Piłsudskiego w Warszawie, Filia w Białej Podlaskiej, ul. Akademicka 2, 21-500 Biała Podlaska, Tel. + 4883 342-87-37, Fax + 4883 342-88-00, e-mail: elzbieta.huk.wieliczuk@ awf-bp.edu.pl

(C) Copyright by the National Institute of Public Health - National Institute of Hygiene 
Wnioski. Rozwijanie odpowiednich nawyków higienicznych i żywieniowych u dzieci jest niezbędnym elementem profilaktyki chorób cywilizacyjnych, w tym próchnicy.

Slowa kluczowe: dzieci w wieku przedszkolnym, próchnica, nawyki żywieniowe i higieniczne

\section{INTRODUCTION}

According to the definition of the World Health Organisation (WHO), dental caries is a local, pathological process of extracorporeal origin leading to the decalcification of enamel, disintegration of hard dental tissue and, as a consequence, to the development of tooth decay [21].

As far as dental caries is concerned, epidemiological data are very distressing [9]. It was proved that dental caries may occur in infants immediately after the occurrence of deciduous teeth [4]. Its prevalence increases with age. In Poland, over 50\% of the children aged 3 have caries, while among older (preschool) children, it may even reach $85 \%$ [18, 27]. A similar problem exists in many countries in Europe [19].

It is alarming that despite the fact that dental caries is common in young children, this problem is often marginalised. Usually, proper oral hygiene begins only in older children, when changes are extensive and irreversible and they require dental procedures or even a root canal treatment leading to tooth death or tooth loss $[11,14]$.

A preschool period is a significant element in shaping positive health-oriented attitudes of a child in preventing dental caries. The aetiology of this disease is mainly related to improper oral hygiene in the first years of life and improper nutritional habits. Moreover, it is important to prepare the youngest ones to take up conscious decisions influencing the state of teeth $[8,28]$.

The aim of this study was to analyse hygienic and nutritional habits in children aged 5 from Biała Podlaska in the context of dental caries prevention.

\section{MATERIAL AND METHODS}

The study included 454 preschool children ( 251 boys and 203 girls) from Biala Podlaska. The inclusion criteria were as follows: 5 years of age, a written consent of their parents/legal guardians to participate in the study. Hygienic and nutritional habits of preschool children were examined by means of a diagnostic survey with the use of an anonymous questionnaire prepared by the authors and completed by parents. Moreover, mean consumption of selected nutrients (calcium, phosphorus and vitamin D) was estimated on the basis of average daily consumption calculated as a mean from three 24-hour interviews (conducted by the authors in a kindergarten or at children's houses). The portion size was determined on the basis of the "Photo album of products and meals" [26]. A nutritional value of a daily portion was calculated with the use of "Dieta 5.0" software (Food and Nutrition Institute in Warsaw). The realisation of nutrition norms was assessed with regard to the Polish nutrition norms (updated in 2012) for children aged 4-6 [10]. In the statistical analysis of differences regarding non-measurable features, a $C h i$-square test was applied with the level of significance at $p<0.05$.

The study was approved by the Research Ethics Commission of Jozef Pilsudski University of Physical Education in Warsaw.

\section{RESULTS}

Assessment of hygienic habits of children from Biala Podlaska

Table 1 (Table 1) presents results regarding oral hygiene in the children under investigation. Over 50\% of the parents declared they had started brushing their children's teeth between their first and second year of life. Only one in three children had their teeth brushed within the first year of life. Approximately $90 \%$ of the preschool children brushed their teeth at least twice a day, including $9 \%$ who brushed their teeth four times a day or more, which was observed slightly more often among girls than boys. The largest group of children $(73.2 \%)$ brushed their teeth in the morning (after breakfast) and in the evening (after supper). Only over $16 \%$ of the girls and nearly $13 \%$ of the boys brushed their teeth after each meal. Half of the children under examination brushed their teeth for 1-2 minutes, while one in three children - for $0.5-1$ minute. Nearly $73 \%$ of the children used a traditional toothbrush.

The process of toothbrushing was supervised by nearly $52 \%$ of the parents, more often among boys than among girls (62.5\% and $38.9 \%$, respectively). The differences were statistically significant (Figure 1).

Table 2 (Table 2) presents the results of research regarding dental appointments of the examined children. According to the parents' responses, $66 \%$ of them visited a dentist regularly once or twice a year. Within the last year, nearly $80 \%$ of the preschool children had a dental appointment, mainly to perform a dental check-up.

\section{Eating habits of the examined children}

The number of meals consumed by the children per day was analysed. It was concluded that the largest 
Table 1. Oral hygiene

\begin{tabular}{|c|c|c|c|}
\hline Specification & Boys & Girls & Total \\
\hline \multicolumn{4}{|l|}{ Age of first tooth brushing } \\
\hline below a year & 29.72 & 32.67 & 31.04 \\
\hline $1-2$ years & 52.61 & 49.50 & 51.22 \\
\hline above 2 years & 17.67 & 17.82 & 17.74 \\
\hline \multicolumn{4}{|l|}{ Frequency of tooth brushing } \\
\hline once a day & 13.15 & 8.46 & 11.06 \\
\hline twice a day & 62.15 & 65.17 & 63.50 \\
\hline three times a day & 17.53 & 15.42 & 16.59 \\
\hline four times a day or more & 7.17 & 10.95 & 8.85 \\
\hline \multicolumn{4}{|l|}{ Time of tooth brushing } \\
\hline after breakfast and after supper & 71.89 & 74.88 & 73.23 \\
\hline after supper only & 11.24 & 5.91 & 8.85 \\
\hline before breakfast only & 0.40 & 0.49 & 0.44 \\
\hline after breakfast only & 3.61 & 1.97 & 2.88 \\
\hline after every meal & 12.85 & 16.75 & 14.60 \\
\hline \multicolumn{4}{|l|}{ Duration of tooth brushing } \\
\hline between 0.5 and $1 \mathrm{~min}$ & 34.6 & 36.4 & 35.36 \\
\hline between 1 and 2 mins & 55.0 & 46.30 & 51.10 \\
\hline between 2 and 3 mins & 10.4 & 17.20 & 13.44 \\
\hline \multicolumn{4}{|l|}{ Type of toothbrush } \\
\hline traditional & 70.90 & 73.9 & 72.25 \\
\hline electric & 29.10 & 26.10 & 27.75 \\
\hline
\end{tabular}

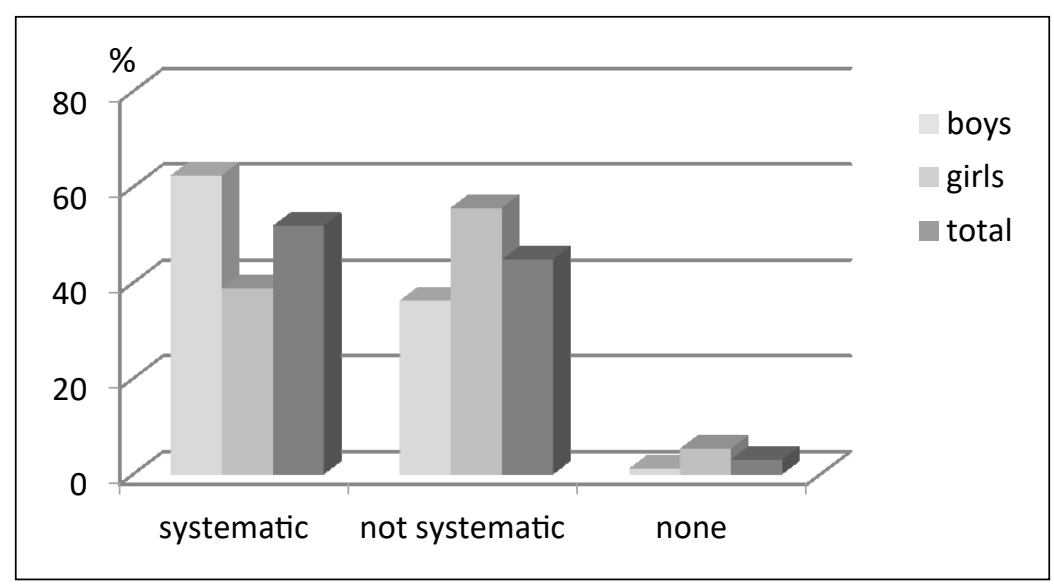

Figure 1. Parents supervising and helping their children brush their teeth (\%)

Table 2. Dental care of the examined children

\begin{tabular}{|l|c|c|c|}
\multicolumn{1}{|c|}{ Specification } & Girls & Boys & Total \\
\hline Frequency of dental appointments & 32.78 & 35.05 & 33.79 \\
\hline once a year & 33.20 & 31.96 & 32.64 \\
\hline every six months & 34.02 & 32.99 & 33.56 \\
\hline less frequently & 62.15 & 63.18 & 62.61 \\
\hline Appointment in the last year & & & \\
\hline Cause of the latest appointment & 81.74 & 76.96 & 79.63 \\
\hline dental check-up & 15.77 & 19.37 & 17.36 \\
\hline toothache & 2.49 & 3.66 & 3.01 \\
\hline injury & & \\
\hline
\end{tabular}


group of the preschool children under investigation usually had 4-5 meals a day (87.9\%). One in 10 children had more than 5 meals (Figure 2).

On the basis of the data included in figure 3, it was observed that the consumption of three basic meals by children was high. Nearly all the preschool children (94.5\%) had dinner every day. Slightly fewer 5 -year-olds had breakfast (89.6\%) and supper (83.8\%). Regular consumption of lunch and an afternoon snack ranged between $72-74 \%$.
In the examined group, $85 \%$ of the preschool children had sweets at least once a week (Figure 4). Moreover, it was noted that over $42 \%$ of the boys and nearly $34 \%$ of the girls had sweet drinks at least once a week. A small percentage $(5.7 \%)$ of the children consumed fast food offered by different food venues. In the case of the last two groups of highly-processed products, the observed differences between gender groups proved to be statistically significant. It was also concluded that over $14 \%$ of the study participants regularly consumed crisps.

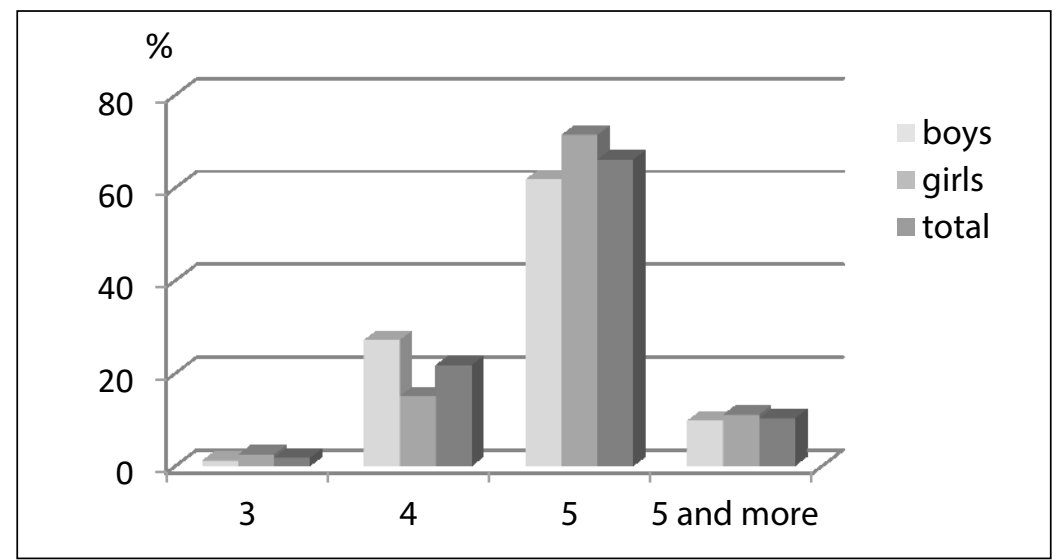

Figure 2. Number of meals consumed by the examined children (\%)

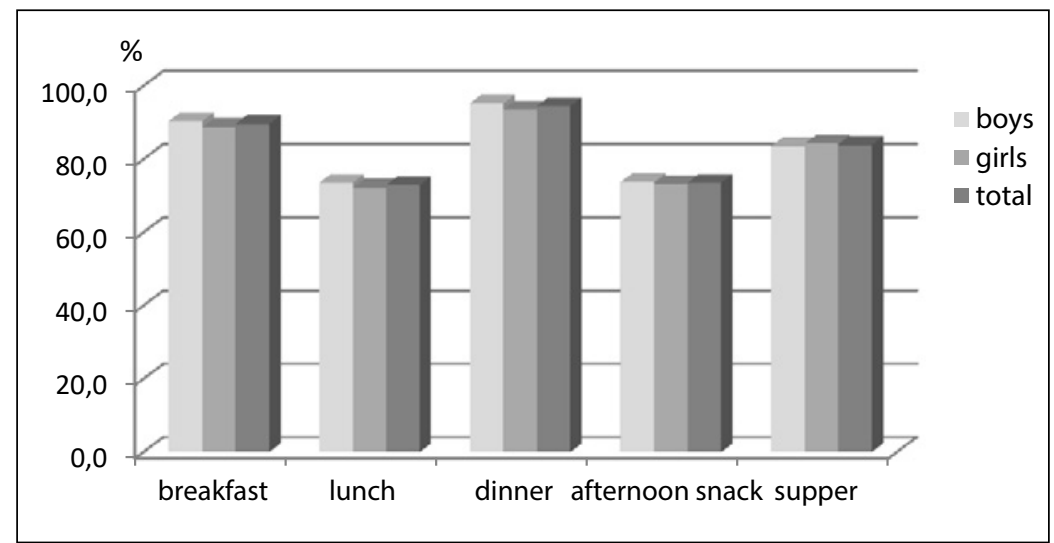

Figure 3. Regularity of meals consumption among the examined children (\%)

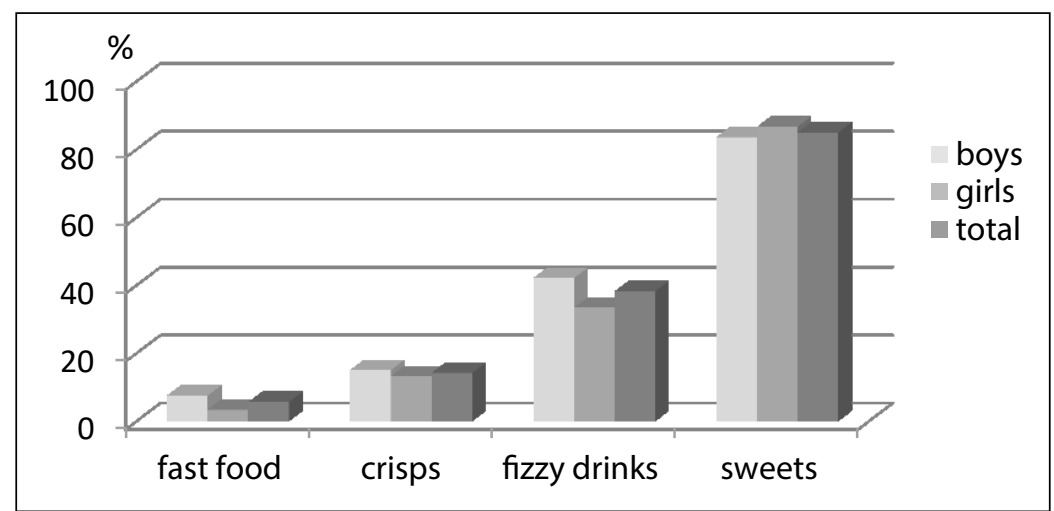

Figure 4. Children who consumed unhealthy products at least once a week (\%) 


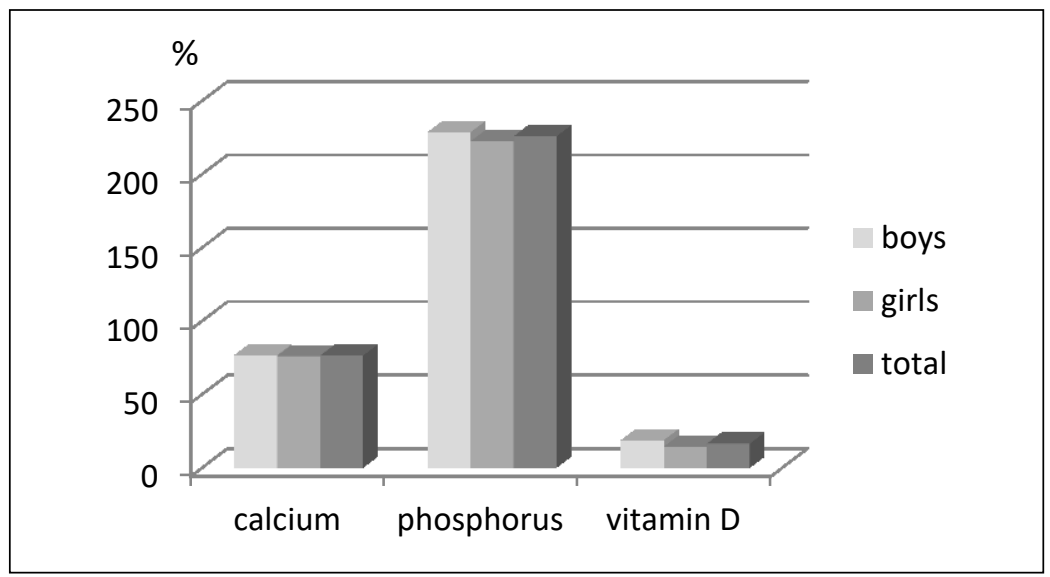

Figure 5. Percentage realisation of the norm for selected nutrients in the diet of the examined children

During the quantitative assessment of the diet of the examined 5-year-old children, an insufficient daily calcium intake was noted. The deficiency of this mineral was at the level of $25 \%$ of the recommended norm. A significant role in preventing caries is played by vitamin $\mathrm{D}$. Its consumption in a daily diet was at the level of $18.9 \%$ among boys and $14.5 \%$ among girls. Moreover, an excessive consumption of phosphorus was noted. Its intake was twice as high as the recommended amount (Figure 5).

\section{DISCUSSION}

Dental caries is strongly determined by systemic and environmental factors as well as by lifestyle. An appropriate state of teeth is influenced by healthoriented attitudes such as a balanced cariostatic diet, proper oral hygiene and regular dental check-ups.

It should be highlighted that nutritional and hygienic habits as well as other health-oriented attitudes are developed and reinforced at preschool age. An important problem is constituted by an improper oral hygiene which leads to the development of dental caries in children.

Apart from the loss of teeth, it leads to speech disorders, difficulties in chewing and gastrointestinal disorders [24]. It must be pointed out that dental caries also poses a high risk for health and life. There are 300-400 species of bacteria in the mouth and several of them may lead to serious health problems. Bacteria destroying teeth and micro-organisms living in compromised structures of periodontium seem to be the most dangerous. These bacteria may be transmitted in blood to various parts of the body such as lungs, joints, optic nerve, kidneys or heart (mainly endocardium) and cause their inflammation. In extreme cases, they may even cause general blood infection, i.e. sepsis.

Preschool children are particularly susceptible to dental caries development. Due to the fact that deciduous teeth are less mineralised, they are more likely to be affected by this condition [12].

Our research revealed that only $31 \%$ of the parents replied that they had performed the first oral hygiene procedures in their children before they reached the age of one. In turn, half of the preschool children started brushing their teeth between the first and the second year of life. Slightly different results were obtained by Bruzda-Zwiech et al. [5], who revealed that in the group of 5-year-olds, over a half of their parents $(51.09 \%)$ applied oral hygiene procedures in the period of the occurrence of the first deciduous teeth (between the $6^{\text {th }}$ and $12^{\text {th }}$ month of life). In turn, in the case of $40.61 \%$ of the children, parents started brushing their teeth only after they turned one and in $8.3 \%$ - only in the $3^{\text {rd }}$ year of life or later.

As it is reported by Brito et al. [3], the prevalence of dental caries in preschool children correlates with the family income lower than minimal monthly income, a low level of education of parents/guardians and the frequency of toothbrushing ( $\mathrm{PR}=1.50$, CI 95\%: 0.50 $4.49, \mathrm{p}=0.001)$.

As far as toothbrushing is concerned, Rajab et al. [22] concluded that the habit of brushing one's teeth at least twice a day was noted statistically more often in children without caries (41\%) than in children with dental caries (24\%). More alarming results regarded $55 \%$ of children from Saudi Arabia aged 6-8 who brushed their teeth less than once a day each week [1]; in this case, $78.1 \%$ of the study participants had dental caries.

In our research, $89 \%$ of the children from Biala Podlaska brushed their teeth at least twice a day, including $25 \%$ who did it three times a day or more. Over $73 \%$ of the preschool children brushed their teeth only after breakfast and supper. The obtained data correspond with the results of the study by BruzdaZwich et al. [5].

According to Szczepańska et al. [25], not performing oral hygiene procedures, removing food debris from 
teeth before going to bed (particularly after an evening meal) in a careless manner or eating snacks just before going to bed constitute the main reasons for dental caries in early childhood. Therefore, parents should learn a proper technique of cleaning teeth.

Toothbrushing should last at least 2-3 minutes under the supervision of parents or guardians. In our research, the process of toothbrushing among the 5 -year-olds from Biala Podlaska was supervised by $52 \%$ of the parents. Lower results were revealed by Rajab et al. [22]; only $19 \%$ of the parents of 6-7-yearold children helped their children brush their teeth. Our research also showed that children from Biala Podlaska brushed their teeth at home for too short a period. Only over $13 \%$ of the 5 -year-olds brushed their teeth for as long as it is recommended.

According to the document of the Ministry of Health entitled "Monitoring the state of oral health in the Polish population in the years 2013-2015", the main oral health problems among Polish preschool children include the lack of dental check-ups of deciduous teeth and insufficient prevention and conservative treatment of dental caries. The above document also revealed that over $60 \%$ of the mothers of 3 -year-old children had not taken their children to a dentist [18]. It should be added that the first dental appointment should take place within 6 months from the appearance of the first deciduous tooth and not later than in the $12^{\text {th }}$ month of life [25]. The results of our research and of BruzdaZwich et al. [5] revealed that parents made the first dental appointment for their children much later.

In order to prevent dental caries, dental checkups should be made every 6 months or more often, depending on individual assessment of the risk of caries in a child. In our study, one in three children visited a dentist twice a year, while nearly $34 \%$ of the examined children had dental check-ups less than once a year, which is an alarming situation.

Dental caries is frequently caused by improper eating habits. An everyday diet of 5-year-old children should consist of 4-5 meals. In our study, almost all the children had meals at such frequency.

Moreover, regularity of meals with breaks between them from 2.5 to 3 hours to allow proper digestion constitutes another fundamentals element of a rational diet. Breaks between meals are significant for preventing dental caries because after 30-60 minutes, $\mathrm{pH}$ of oral cavity returns to a safe level which protects tooth enamel from dental caries bacteria multiplication. In our study, times of meals were compliant with the above recommendation.

Moreover, an appropriate intake of calcium and vitamin D is significant for proper development and mineralisation of children's teeth. Our study revealed an insufficient intake of the above elements in everyday diet.
The obtained results correspond with the findings of other authors [20]. An insufficient intake of calcium in a diet is a negative phenomenon, particularly dangerous for children, as it may lead to the weakening of osseous tissue. This, in turn, may lead to spine deformities, decalcification of the body, tooth decay and an increased risk of osteopenia or osteoporosis in adult life [7]. Moreover, a chronic calcium deficiency in a diet is related to an increased risk of cardiovascular diseases and cerebral stroke in the future [6]. In turn, vitamin D deficiency decreases the level of calcium in blood plasma, which leads to the osseous system disorders [15].

Although phosphorus and calcium are responsible for the construction of bones, it is highly significant for these two elements to be included in similar amounts in a diet, particularly in the period of intensive development and growth of bones. However, the results of our research clearly indicate that the amount of phosphorus in daily food rations of the examined children was significantly higher than the amount of calcium. A high intake of phosphorus in a diet may lead to significant changes in calcium metabolism, which hinders its absorption from the gastrointestinal tract. Moreover, an excessive intake of phosphorus limits the absorption of other minerals, e.g. zinc, magnesium, iron or copper. Numerous studies indicated that the intake of this microelement in the diet of Polish children and adolescents is too high $[6,23]$.

What is more, approximately $6 \%$ of preschool children from Biala Podlaska consumed unhealthy fast food. According to Wierzejska [29], the majority of preschool children ate these products and declared they were their favourite types of food. As Krzywiec et al. report [16], the presence of fast food products in a diet disturbs the absorption of proper protein from the gastrointestinal tract, which leads to increased vulnerability to dental caries. Moreover, such products include considerable amounts of fat, with the dominating amounts of saturates and trans fatty acids. Clinical studies revealed that atherosclerotic processes may begin already in childhood. Particular products are also a significant source of acrylamide in the diet of children and youth; it is a substance perceived as genotoxic and carcinogenic and its consumption may pose a risk for human health. Konings et al. [13] estimated that in the group of children aged 1-6, fast food products and snacks supplied $90 \%$ of all acrylamide in a diet, where $58 \%$ was supplied by chips and crisps. Moreover, consuming fast food products also increases the risk of obesity and type 2 diabetes.

Prevention is particularly significant in reducing the risk of dental caries. Preventive measures include, inter alia, promoting non-cariogenic diet (avoiding or reducing the amount of sucrose, glucose and fructose 
in a diet, limiting the amount of snacks between the main meals). In our research, as many as $85 \%$ of preschool children consumed sweets at least once a week. An increase in the concentration of sugars supplied in food leads to adaptive changes among bacteria in dental plaque. Bacteria become more resistant to acids and they increase their acidifying properties even by several times, which is a highly cariogenic factor [16]. Moreover, as Joyce and Gibney report [12], consuming sweets or sweetening products considerably lowers their nutritional value and may lead to the deficiency of magnesium, calcium, vitamin $\mathrm{B}$ and $\mathrm{C}$ as well as protein and fibre. Apart from cariogenic properties, sugar negatively affects the process of chewing and digesting and disturbs the work of the whole gastrointestinal tract.

The development of dental caries is also affected by consuming sugary drinks, particularly in the evening [17]. In our research, it was noted that over $42 \%$ of the boys and nearly $34 \%$ of the girls drank them at least once a week. Sweet drinks belong to a group of products with a very low $\mathrm{pH}$, which is between 2.1 and 4.46 , i.e. below the critical level for enamel. A harmful influence may also be exerted by sour fruit juices and sweetened fizzy drinks which include large amounts of sugar and acids.

To sum up, shaping proper hygienic and nutritional habits is an indispensable element of preventing lifestyle diseases, including dental caries. In particular, educational programmes should be directed at parents as children learn these habits from them.

\section{CONCLUSIONS}

There is a need for pro-health education of preschool children and their parents in the field of proper oral hygiene, particularly in terms of their knowledge regarding the age at which toothbrushing should start, the frequency of toothbrushing and regular dental check-ups.

It was revealed that the most common improper nutritional habits which may lead to dental caries among children include an excessive consumption of sweets and sugary drinks.

An insufficient supply of calcium and vitamin $\mathrm{D}$ in a daily diet of children was noted, which may negatively affect their bone system, including teeth.

Highly processed products as well as products high in preservatives should be limited in children's diet due to the fact that an excessive intake of phosphorus reduces the absorption of calcium from the gastrointestinal tract.

\section{Conflict of interest}

The authors declare no conflict of interest.

\section{REFERENCES}

1. Alhabdan Y.A., Albeshr A.G., Yenugadhati N., Jradi $H$.: Prevalence of dental caries and associated factors among primary school children: a population-based cross-sectional study in Riyadh, Saudi Arabia. Environ Health Prev Med 2018;30;23(1):60. DOI: 10.1186/ s12199-018-0750-z.

2. Bissar A., Schiller P., Wolff A., Niekusch U., Schulte A.G.: Factors contributing to severe early childhood caries in south-west Germany. Clin Oral Investig 2014;18:1411-1418. DOI: 10.1007/s00784-013-1116-y

3. Brito Á.S., Clementino M.A., Gomes M.C., Barbosa Neves E.T., Barbosa A.S., de Medeiros C.A., de Aquino M.M., Granvile - Gracia A.F., de Menezes V.A.: Sociodemographic and behavioral factors associated with dental caries in preschool children: Analysis using a decision tree. J Indian Soc Pedod Prev Dent 2018;36(3):244-249. DOI: 10.4103/JISPPD. JISPPD 21017.

4. Brown J.P.: Dental caries prediction to target high-risk individuals in community-based preventive programs is problematic. J Evid Based Dent Pract 2010;10:241-243.

5. Bruzda-Zwiech A., Filipińska R., SzydłowskaWalendowska B. Lubowiedzka-Gontarek B., WochnaSobańska M: Stomatologiczne zachowania prozdrowotne 4-5-letnich dzieci w świetle badań ankietowych rodziców [Oral Health Behaviors of 4 to 5-Year-Old Children - Parent Questionnaire Survey]. Dent Med Probl 2012;49(2):272-278. (in Polish)

6. Charzewska J. (red.): Rekomendacje dla realizatorów żywienia z zakresu zasad prawidłowego żywienia dzieci w przedszkolach [Recommendations for food contractors regarding the principles of proper nutrition of children in kindergartens]. Warszawa, Instytut Żywności i Żywienia, 2011. (In Polish)

7. Elders P.J., Lips P., Netelenbos J.C., van Ginkel F.C., Khoe E., van der Vijgh W.J., van der Stelt P.F.: Long-term effect of calcium supplementation on bone loss in perimenopausal women. J Bone Miner Res 1994;9:963-970.

8. Flanders R.A. Effectiveness of dental health educational programs in schools. J Am Dent Assoc 1987;114:239-143.

9. Huk-Wieliczuk E., Czeczuk A., Michalska A., WójtowiczChomicz K.: Ryzyko rozwoju osteoporozy u sportowców wyczynowych. [The risk of osteoporosis in professional athletes] In: Maciag K., Maciag A. eds. Zadania i wyzwania medycyny - charakterystyka problemów i postępowania terapeutycznego. Lublin Tygiel, 2018; 2130 (in Polish)

10. Jarosz M.: Normy żywienia dla populacji polskiej - nowelizacja [Nutrition standards for the Polish population - amendment]. IŻŻ, Warszawa, 2012.

11.Johnsen D.C., Gerstenmaier J.H., DiSantis T.A., Berkowitz R.J.: Susceptibility of nursing-caries children to future approximal molar decay. Pediatric Dentistry 1986, 8(3): 168-170.

12.Joyce T., Gibney M.J.: The impact of added sugar consumption on overall dietary quality In Irish children and teenagers. J Hum Nutr Diet 2008; 21: 438-450 
13. Konings E.J., Baars A.J., van Klaveren J.D., Spanjer M.C., Rensen P.M., Hiemsta M., van Kooij J.A., Peters $P . W .:$ Acrylamide exposure from foods of the Dutch population and an assessment of the consequent risks. Food Chem Toxicol 2003, 41(11): 1569-1579.

14. Krol D.M.: Dental caries, oral health and pediatricians. Curr Probl Pediatr Adolesc Health Care 2003, 33(8): 253-270

15. Krol E., Sobiech M., Krejpcio Z. Ocena spożycia składników mineralnych $\mathrm{w}$ całodziennych racjach pokarmowych wybranej grupy wegetarian i nie wegetarian [Evaluation of the dietary intake of minerals in the daily food rations of vegetarians and nonvegetarians]. Żywność. Nauka. Technologia. Jakość 2005;2(43), Suppl:114-120. (in Polish)

16.Krzywiec E., Zalewska M., Wójcicka A. Robert Jabłońskil, Beata Janina Olejnik B.J., Zyta Grabowska S., Jamiołkowski J., Czerech E., Luszcz A., Stepek A., Maciorkowska E.: Wybrane zachowania żywieniowe a występowanie próchnicy u młodzieży [Selected eating habits and caries occurrence in adolescents] Przegl Epidemiol 2012;66:713-721. (in Polish)

17. Lee J.G., Messer L.B.: Intake of sweet drinks and sweet treats versus reported and observed caries experience. Eur Arch Paediatr Dent 2010;11(1):5-17.

18. Monitorowanie stanu zdrowia jamy ustnej populacji polskiej w latach 2013-2015 [Monitoring of the oral health of the Polish population in 2013-2015], Minister Zdrowia, Program na lata 2013 - 2015 (in Polish)

19. Olczak-Kowalczyk D., Gozdowski D., Kaczmarek U.: Próchnica zębów stałych u dzieci w wieku 5 i 7 lat w Polsce i jej związek z próchnicą zębów mlecznych [Dental caries in permanent dentition in children aged 5 and 7 in Poland and its association with dental caries in primary dentition]. Nowa Stomatol 2017;22(3):129-141. (in Polish)

20.Orkusz A., Włodarczyk A.: Ocena żywienia dzieci w wieku przedszkolnym na podstawie jadłospisów [Evaluation of the nutritional value of nursery school meals], Nauki Inżynierskie i Technologie, Engineering Sciences and Technologies, 2014;1(12):72-81.
21. Petersen P.E. Priorities for research for oral health in the 21st Century - the approach of the WHO Global Oral Health Programme. Community Dental Health 2005; 22:71-74

22.Rajab L.D., Petersen P.E., Bakaaen G., Hamdan M.A.: Oral health behaviour of schoolchildren and parents in Jordan. Int J Paediatr Dent 2002;12:168-176.

23. Sochacka-Tatara E., Jacek R., Sowa A. Musiat A.: Ocena sposobu żywienia dzieci w wieku przedszkolnym [Assessment of preschool children's diet]. Probl Hig Epidemiol 2008;89(3):389-394. (in Polish)

24.Soltan E., Herman K., Jankowska K., KowalczykZając M: Ocena stanu uzębienia u 4-5-letnich dzieci wrocławskich. [Assessment of the State of Dentition among 4-5-Year-Old Children from the City of Wrocław]. Dent Med Probl 2004;3:423-426. (in Polish)

25.Szczepańska J., Szydłowska B., Lubowiedzka B., Pawtowska E.: Analysis of risk factors for caries in 3-year old children. Czas Stomatol 2007;60.3:162-170.

26.Szponar L., Wolnicka K., Rychlik E.: Album fotografii i produktów i potraw [Album of photographs of food products and dishes]. IZZŻ, Warszawa, 2000.

27. Szymańska J., Szalewski L.: Próchnica zębów mlecznych w populacji polskich dzieci w wieku 0,5-6 lat. [Deciduous teeth caries in the population of Polish children aged 0.5-6 years]. Zdr Publ 2011;121(1):86-89. (in Polish)

28. Wiener R.C., Crout R.J., Wiener M.A.: Toothpaste use by children, oral hygiene, and nutritional education: an assessment of parental performance. J Dent Hyg 2009;83(3):141-145

29. Wierzejska R.: Znaczenie prawidłowego żywienia dzieci w wieku przedszkolnym [The importance of proper nutrition of preschool children] In: Charzewska J. (eds) Rekomendacje dla realizatorów żywienia z zakresu zasad prawidłowego żywienia dzieci w przedszkolach Warszawa, IŻŻ, 2011: 9-15 (in Polish). Available at: https://ncez.pl/upload/rekomendacje-ksia-z-ka.pdf

Received: 12.02 .2020

Accepted: 27.04.2020 